The assays were supported by grants from the Medical Research Council and the Board of Governors of St. Bartholomew's Hospital, and were performed by Miss Linda Howard.

We are grateful to the medical and nursing staff of the diabetic pregnancy unit at King's College Hospital for their co-operation in this study.

\section{References}

Beck, P., and Daughaday, W. H. (1967). Fournal of Clinical Investigation, 46, 103.

Beck, P., Parker, M. L., and Daughaday, W. H. (1965). fournal of Clinical Endocrinology and Metabolism, 25, 1457.

Brudenell, M. J., and Beard, R. W. (1972). Clinics in Endocrinology and Metabolism, 1,673 .

Costrini, N. V., and Kalkhoff, R. K. (1971). Fournal of Clinical Investigation, 50, 992.

Genazzani, A. R., et al. (1971). Fournal of Obstetrics and Gynaecology of the British Commonwealth, 78, 577.

Grumbach, M. M., Kaplan, S. L., Abrams, C. L., Bell, J. J., and Conte, F. A. (1966). Fournal of Clinical Endocrinology and Metabolism, 26, 478.
Haour, F., Cohen, M., and Bertrand, J. (1971). Revue Européenne d'Etudes Cliniques et Biologiques, 16, 124.

Josimovich, J. B., Koser, B., Boccella, L., Mintz, D. H., and Hutchinson, D. L. (1970). Obstetrics and Gynecology, 36, 244

Kalkhoff, R. K. (1969). Diabetes, 18, 153.

Kalkhoff, R. K., Jacobson, M., and Lemper, D. (1970). Fournal of Clinical Endocrinology and Metabolism, 31, 24.

Letchworth, A. T., Boardman, R. J., Bristow, C., Landon, J., and Chard, T. (1971). Fournal of Obstetrics and Gynaecology of the British Commonwealth, 78, 542 .

Letchworth, A. T., and Chard, T. (1972a). Fournal of Obstetrics and Gynaecology of the British Commonwealth, 79, 680 .

Letchworth, A. T., and Chard, T. (1972b). Lancet, 1, 704

Samaan, N., Yen, S. C. C., Gonzalez, D., and Pearson, O. H. (1968). fournal of Clinical Endocrinology and Metabolism, 28, 485

Samaan, N. A., Gallager, H. S., McRoberts, W. A., and Faris, A. M. jun. (1971). American fournal of Obstetrics and Gynecology, 109, 63.

Saxena, B. N., Emerson, K., and Selenkow, H. A. (1969). New England fournal of Medicine, $281,225$.

Selenkow, H. A. (1971). Diabetes, 40, 696.

Singer, W., Desjardins, P., and Friesen, H. G. (1970). Obstetrics and Gynecology, 36, 222.

Spellacy, W. N., Teoh, E. S., Buhi, W. C., Birk, S. A., and McCreary, S. A. (1971). American fournal of Obstetrics and Gynecology, 109, 588.

Spona, J., and Janisch, H. (1971). Acta Endocrinologica (Kobenhavn), 68, 401.

Zuckerman, J. E., Fallon, V., Tashiian, A. H., jun., Levine, L., and Friesen,

H. G. (1970). Fournal of Clinical Endocrinology and Metabolism, 30, 769.

\title{
Clinical and Laboratory Double-blind Investigation on Effect of Fibrinolytic Therapy in Patients with Cutaneous Vasculitis
}

\author{
B. DODMAN, W. J. CUNLIFFE, B. E. ROBERTS, R. SIBBALD
}

British Medical fournal, 1973, 2, 82-84

\section{Summary}

The effects of phenformin and ethyloestrenol and phenformin and stanozolol on the clinical state, plasma fibrinolytic activity, and fibrinogen-fibrin-related antigen (F.R.-antigen) were compared with placebo in 13 patients with cutaneous vasculitis. Eight patients showed considerable clinical improvement when taking phenformin and an anabolic steroid; an impaired fibrinolytic activity before treatment favoured clinical improvement.

\section{Introduction}

Cutaneous vasculitis refers to a miscellaneous group of conditions in which one of the primary histological defects is inflammation of the skin blood vessels; fibrinoid necrosis and vasular occlusion may follow. The clinical picture depends on the site, size, and number of vessels affected, and so one may see any combination of purpura, papules, nodules, necrosis, and even ulceration. The pathogenesis, however, is unknown but recent investigations (Cochrane, 1968; Katz et al., 1968; Cream, 1972) have suggested that immunological phenomena such as precipitation of immune complexes may be important. As a result of the immunological reaction occurring within the blood vessel wall or lumen a series of

\section{Leeds General Infirmary, Leeds 1}

W. J. CUNLIFFE, M.D., M.R.C.P., Consultant Dermatologist B. E. ROBERTS, M.D., M.R.C.PATH., Consultant Haematologist B. DODMAN, M.B., CH.B., Senior House Officer, Research Assistant Pontefract General Hospital, Southgate, Pontefract WF8 1PL R. SIBBALD, M.B., M.R.C.PATH., Consultant Pathologist events follow which may culminate in the formation of a thrombus. Investigations of blood coagulation factors are limited (Isacson et al., 1970) and appear at the moment to be of little help in the understanding of the development of the vasculitic lesion. Studies of fibrinolysis, however, have been more detailed and interesting. Cunliffe (1968) reported three patients who had a persistently reduced fibrinolytic activity as shown by a prolonged euglobulin lysis time, and which returned to normal in two cases as the vasculitis spontaneously healed.

Cunliffe and Menon (1971) further investigated 52 patients with a vasculitis predominantly affecting the skin. Of these, 32 patients had a significantly reduced plasma fibrinolytic activity. The same authors reported in an uncontrolled study that in nine out of 10 patients who received oral fibrinolytic therapy with phenformin hydrochloride and ethyloestrenol clinical improvement occurred over a period of 6-36 weeks. Isacson et al., (1970) reported a decreased blood fibrinolytic activity in four of 11 patients with chronic vasculitic lesions of the lower legs. Parish (1972) also reported eight patients six of whom had a decreased blood fibrinolytic activity. In contrast to these findings, however, Kurban and Ryan (1969) and Vaithianathan and Takats (1968) were unable to detect a reduced fibrinolytic activity in patients with a vasculitis.

Published data on the treatment of cutaneous vasculitis with fibrinolytic therapy from other centres are not available. Clearly, therefore, the field was set for a more detailed, preferably double-blind study of oral fibrinolytic therapy in patients with chronic vasculitis. At the same time it appeared prudent to measure fibrinogen-fibrin-related antigen (F.R.-antigen) in these patients with a demonstrable disorder of their fibrinolytic mechanisms.

\section{Patients and Methods}

Each of the 13 patients who entered the trial had a vasculitis of at least six months' duration and the clinical details are 
given in table I. Therapy consisted of either phenformin (slow release) $50 \mathrm{mg}$ twice a day and ethyloestrenol $2 \mathrm{mg}$ four times a day or phenformin (slow release) $50 \mathrm{mg}$ twice a day and stanozolol $5 \mathrm{mg}$ twice a day or matched placebo tablets.

The treatment was changed three monthly by the pharmacist without the knowledge of the patient or investigator.

Before treatment and at monthly intervals the clinical picture was assesssed and fibrinolytic activity and F.R.-antigen level estimated.

The clinical assessment was graded according to the distribution, number, frequency, severity, and persistence of the lesions. Grade 0-6 indicated an increasing order of severity for each patient before and during the trial.

Fibrinolytic activity of the plasma was assessed by the euglobulin lysis time, which was estimated by the method of von Kaulla (1963) as modified by Menon (1967) using an automatic euglobulin clot-lysis recorder (Carmanen Instruments Ltd.). The F.R.-antigen titre was measured by the tanned red cell haemagglutination inhibition technique of Merskey et al., (1966).

Before treatment diabetes mellitus was excluded and urea and liver function tests were checked on each visit.

\section{Results}

Altogether, 12 patients completed the full nine months of the trial; of these, seven did well clinically when treated with either phenformin and ethyloestrenol or phenformin and stanozolol whereas the other five failed to show any significant improvement whatsoever (table I). One patient (case 13) was withdrawn from the trial at the fourth month. This patient, with a chronic panniculitis unresponsive to steroids, improved greatly during the first three months when on phenformin and stanozolol. When therapy was changed to the placebo extensive recurrence of the panniculitis occurred and the treatment code had to be broken. The patient has since been treated satisfactorily with phenformin and stanozolol or phenformin and ethyloestrenol. On two occasions his therapy was discontinued and this was associated with a relapse of his panniculitis and a decrease in his blood fibrinolytic activity to 320 minutes. In one of these relapses a biopsy specimen of normal leg skin was taken for tissue fibrinolytic studies (Dodman et al., 1973) and the biopsy site developed into an extensive panniculitic lesion. This was in contrast to a biopsy specimen taken while on treatment, when the biopsy site healed well.

Of the other 12 subjects there was no particular diagnostic group of patients who appeared to respond better than others and neither drug combination was superior to the other. The fibrinolytic activity before and during the trial in one patient (case 1) who clinically had a good response with almost complete resolution of the rash during active treatment is shown in fig. 1. Apart from one result, the fibrinolytic therapy maintained an improved fibrinolytic state during the phase of clinical remission. The patient was under observation for a further 54 weeks after completing the trial (fig. 1). During this time his rash was under good control when taking either phenformin and ethylestrenol or phenformin and stanozolol; these drugs producing an improved fibrinolytic state. When the drugs were discontinued for 16 weeks his rash returned to its original severity and his fibrinolytic activity became impaired. For 18 weeks he was also treated with stanozolol alone. Although this maintained a normal fibrinolytic activity his rash was less well controlled than on the combination therapy.

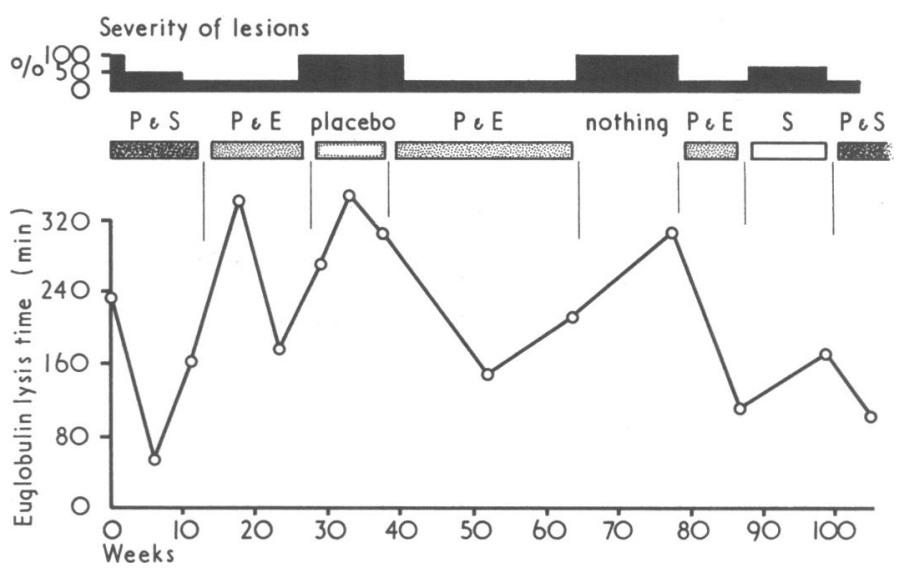

FIG. 1-Clinical response and fibrinolytic activity in case 1 during trial and for subsequent 12 months. $\mathrm{P}=$ Phenformin. $\mathrm{S}=$ Stanozolol. $\mathrm{E}=$ Ethyloestrenol.

The fibrinolytic activity of one of the five patients who showed no clinical improvement is illustrated in fig. 2. Although there was no clinical improvement there was an improved blood fibrinolytic activity with active therapy.

The overall fibrinolytic response to drug therapy is given in table II. With the placebo treatment there was no increase or decrease in the fibrinolytic activity but on active therapy the fibrinolytic activity was significantly improved. Phenformin and stanozolol increased the fibrinolytic activity more than phenformin and ethylestrenol when comparison is made of the 12 subjects who completed the nine months' trial but the difference was not significant (P 0.2). However, a paired $t$

TABLE I-Clinical Details and Response to Treatment (Grade 0-6 Indicates the Increasing Order of Severity)

\begin{tabular}{|c|c|c|c|c|c|c|c|c|c|c|c|c|c|}
\hline \multirow{2}{*}{$\begin{array}{l}\text { Case } \\
\text { No. }\end{array}$} & \multirow{2}{*}{ Sex } & \multirow{2}{*}{ Age } & \multirow{2}{*}{\multicolumn{7}{|c|}{ Diagnosis }} & \multicolumn{4}{|c|}{ Grading } \\
\hline & & & & & & & & & & Initial & $\underset{(\text { Mean 2.92) }}{\mathbf{P}+\mathbf{E}}$ & $\underset{\text { (Mean 3.00) }}{\mathbf{P}+\mathbf{S}}$ & $\begin{array}{c}\text { Placebo } \\
\text { (Mean 5.08) }\end{array}$ \\
\hline $\begin{array}{r}1 \\
2 \\
3 \\
4 \\
5 \\
6 \\
7 \\
8 \\
9 \\
10 \\
11 \\
12 \\
13\end{array}$ & $\begin{array}{l}\text { F. } \\
\text { F. } \\
\text { F. } \\
\text { F. } \\
\text { F. } \\
F . \\
\text { F. } \\
\text { F. } \\
M . \\
M . \\
M\end{array}$ & $\begin{array}{l}59 \\
52 \\
62 \\
45 \\
70 \\
46 \\
54 \\
50 \\
16 \\
56 \\
32 \\
14 \\
41\end{array}$ & $\begin{array}{l}\text { Nodular vasculitis* } \\
\text { Nodular vasculitis ... } \\
\text { Nodular vasculitis } \\
\text { Erythema nodosum } \\
\text { Rheumatoid vasculitis } \dagger \\
\text { Purpuric vascilutis } \\
\text { Erythema induratum } \\
\text { Recurrent phlebitis } \\
\text { Pityriasis lichenoides ch } \\
\text { Recurrent phlebitis and } \\
\text { Pityriasis lichenoides ch } \\
\text { Pityriasis lichenoides ch } \\
\text { Panniculitis }{ }^{11} \text {.. }\end{array}$ & 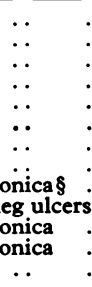 & $\begin{array}{l}\because \\
\because \\
\therefore \\
\because \\
\because \\
\therefore \\
\because \\
\because \\
\because \\
\therefore\end{array}$ & $\begin{array}{l}\because \\
\because \\
\because \\
\because \\
\because \\
\because \\
\because \\
\cdots \\
\cdots\end{array}$ & $\begin{array}{l}\ldots \\
\because \\
\therefore \\
\because \\
\because \\
\because \\
\because \\
\because \\
\therefore\end{array}$ & $\begin{array}{l}\ldots \\
\because \\
\ldots \\
\because \\
\cdots \\
\ldots \\
\cdots \\
\cdots \\
\cdots\end{array}$ & $\begin{array}{l}\because \\
\because \\
\therefore \\
\because \\
\therefore \\
\therefore \\
\because \\
\because \\
\because \\
\therefore\end{array}$ & $\begin{array}{l}5 \\
5 \\
5 \\
5 \\
5 \\
5 \\
5 \\
5 \\
5 \\
5 \\
5 \\
5 \\
5\end{array}$ & $\begin{array}{l}0 \\
6 \\
3 \\
1 \\
3 \\
5 \\
0 \\
3 \\
5 \\
6 \\
1 \\
4 \\
1\end{array}$ & $\begin{array}{l}0 \\
5 \\
0 \\
2 \\
2 \\
5 \\
0 \\
4 \\
6 \\
5 \\
2 \\
5 \\
-\end{array}$ & $\begin{array}{l}6 \\
5 \\
6 \\
5 \\
6 \\
6 \\
3 \\
6 \\
5 \\
5 \\
5 \\
3 \\
5\end{array}$ \\
\hline
\end{tabular}

- Nodular vasculitis = Large tender nodules of the anterior and posterior calf; rarely ulcerate. $\uparrow$ Rheumatoid vasculitis = Papules or nodules often haemorrhagic, and of widespread distribution small haemorrhagic papules and small areas of ulceration. Panniculitis = Large tender deep nodules usually on the lower limbs; may ulcerate. 


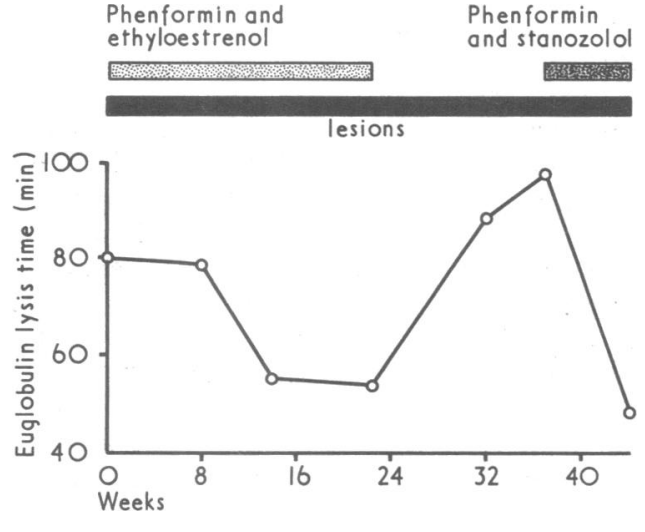

FIG. 2-Clinical response and fibrinolytic activity in case 6.

test comparing the successfully and unsuccessfully treated groups showed that the fibrinolytic activity during the pretreatment and placebo periods was significantly impaired $(\mathrm{P}<0.05)$ in those patients who had a satisfactory clinical response to therapy. There was no increase in F.R.-antigen either before or during treatment (table III).

TABLE II-Euglobulin Lysis Time (Mean \pm S.E. of Mean) Before and During Trial

\begin{tabular}{l|r|r|r|c}
\hline \multicolumn{1}{c|}{ Therapy (If Any) } & $\begin{array}{c}\text { Overall } \\
\text { Data (A) }\end{array}$ & $\begin{array}{c}\text { Successful } \\
\text { Group (B) }\end{array}$ & $\begin{array}{c}\text { Un- } \\
\text { successful } \\
\text { Group (C) }\end{array}$ & $\begin{array}{c}\text { Statistical } \\
\text { Comparison } \\
\text { of B and C }\end{array}$ \\
\hline $\begin{array}{l}\text { Phenformin and } \\
\text { Stanozolol } \\
\begin{array}{l}\text { Phenformin and } \\
\text { Ethyloestrenol }\end{array} \\
\begin{array}{l}\text { Pretreatment and } \\
\text { Placebo }\end{array}\end{array}$ & $89 \cdot 2 \pm 7.3$ & $93.6 \pm 9.3$ & $79 \cdot 3 \pm 0.8$ & N.S. \\
\hline
\end{tabular}

N.S. $=$ Not significant.

TABLE III-F.R.-antigen Before and During Trial. Figures are Mean \pm S.E. of Mean

\begin{tabular}{|c|c|c|}
\hline & & F.R.-antigen $(\mu \mathrm{g} / \mathrm{ml})$ \\
\hline $\begin{array}{l}\text { Before treatment } \quad . \\
\text { Placebo } \\
\text { Phenformin and Stanozolol } \\
\text { Phenformin and Ethyloestrenol }\end{array}$ & $\begin{array}{l}\cdots \\
\cdots \\
\cdots\end{array}$ & $\begin{array}{l}5.68 \pm 0.86 \\
5.78 \pm 0.96 \\
6.39 \pm 1.84 \\
5.0 \pm 1.03\end{array}$ \\
\hline
\end{tabular}

\section{Discussion}

This report clearly shows that fibrinolytic therapy with phenformin and an anabolic steroid may help certain patients with vasculitis. Our data also show that some patients with vasculitis do have a reduced blood fibrinolytic activity, and this accords with previous observations (Cunliffe, 1968; Isacson et al., 1970; Cunliffe and Menon, 1971; Parish, 1972).
Gallimore et al. (1972) have shown in experimental studies that fibrin deposition within the circulation is necessary before increased F.R.-antigen levels are produced by a vigorous fibrinolytic state. Although fibrin deposition is a feature of certain types of vasculitis (Isacson et al., 1970) no difference in the F.R.-antigen levels between treated and control groups could be detected. This finding is in keeping with the report of Gormsen and Vad (1970) who found no increase in F.R.antigen levels in normal subjects after oral fibrinolytic therapy, and contrasts with the finding of Fernley et al. (1969). However, F.R.-antigen levels were measured at monthly intervals and it is possible that a significant increase in the first few days of treatment was missed.

Our data suggest that the combination of phenformin and stanozolol and phenformin and ethlyloestrenol have similar effects on the clinical state and blood fibrinolytic activity. In the one patient who received an anabolic steroid alone the blood fibrinolytic activity was maintained at a satisfactory level. This effect is in agreement with the work of Davidson et al. (1972) but stanozolol alone appeared to be less effective clinically than the combination therapy.

In support of the importance of impaired fibrinolysis in patients with cutaneous vasculitis is our observation that a diminished fibrinolytic activity during the natural course of the disease favours clinical improvement when treated with fibrinolytic therapy. We are, however, not surprised to observe that not all patients have a diminished fibrinolytic activity and that not all respond to treatment, since fibrinolytic mechanisms are only one of several variables involved in the pathogenesis of vasculitis. There is no doubt, however, that in many otherwise refractory cases this form of therapy is of demonstrable value.

We are grateful to the Medical Research Council and to Organon Laboratories Ltd. and Winthrop Laboratories Ltd. for financial help, and to Mr. C. Margolis for the gift of a lysis recorder. We thank our West Riding colleagues for referring patients, Mr. C. Buchan, Mr. R. A. Forster, and Mrs. C. Horner for technical help, and Mrs. L. Lane for secretarial help.

Requests for reprints should be addressed to: Dr. W. J. Cunliffe, Leeds General Infirmary, Leeds 1.

\section{References}

Cochrane, C. G. (1968). fournal of Allergy, 42, 113.

Cream, J. J. (1972). Paper read at the British Association of Dermatology, January, 1972 .

Cunliffe, W. J. (1968). Lancet, 1, 1126.

Cunliffe, W. J. (1968). Lancet, 1, 1126.19 . British fournal of Dermatology, $84,99$.

Dodman, B., Cunliffe, W. J., and Roberts, B. E. (1973). British fournal of Dermatology. In press:

Fearnley, G. R., Chakraborti, R., and Evans, F. (1969). Lancet, 1, 910. Gallimore, M. J., Tyler, H. M., and Shaw, T. B. (1972). Fournal of American
Pathology, 25, 185 .

Gormsen, J., and Vad, A. (1970). Scandinavian fournal of Haematology, 7,261 .

Isacson, S., Lineli, F., Moller, H., and Nilsson, I. M. (1970). Acta Dermato-

Venereologica, 50, 213 .
Katz, D. H., Unane, E. R., and Dixon, F. J. (1968). Fournal of American Pathology, 53, 835.

Kurban, A. K., and Ryan, T. J. (1969). Transactions at the St. Fohn's Hospital Dermatological Society, 55, 218.

Dermatological Society, 55, 218.
Menon, I. S. (1967). Lancet, 1, 116.

Menon, I. S. (1967). Lancet, 1, 116.

Merskey, C., Kleiner, G. J., and Johnson, A. S. (1972). Proceedings of the Royal Society of Medicine, 65, 276. Parish, W. E. (1972). Proceedings of the Royal Society of Medici
Vaithianathan, T., and Takats, G. De. (1968). Lancet, $2,108$.

Von Kaulla, K. W. (1963). Chemistry of Thrombolysis: Human Fibrinolytic Enzymes, p. 79. Springfield, Illinois, Thomas. 